\title{
Performance Evaluation of Dimoro Irrigation Area Based on Rating Scale Methods
}

\author{
Dian Retno Anugrah ${ }^{1,3}$, Sobriyah ${ }^{2}$, Dewi Handayani \\ ${ }^{1}$ Student of master program of Civil Engineering, Sebelas Maret University, Jl. Ir. Sutami 36A \\ Surakarta \\ ${ }^{2}$ Lecturer of master program of Civil Engineering, Sebelas Maret University, Jl. Ir. Sutami 36A \\ Surakarta \\ ${ }^{3}$ Dinas Pekerjaan Umum Kabupaten Karanganyar, Jl. Lawu No.341 Kompleks Perkantoran \\ Karanganyar \\ E-mail: dr_anugrah@yahoo.com
}

\begin{abstract}
Sustainable operation and maintenance activities determine durability and success level of irrigation infrastructure. Success indicator of irrigation such as increasing of water usage efficiency, increasing of plant intensity, decreasing of water distribution conflict, increasing of agricultural production result and decreasing of dryness of plant. Therefore, it is necessary to have research to determine the performance of irrigation operation that had been carried out from 2013 - 2106 at Dimoro Irrigation Area. The Dimoro operational data records 2013 - 2016 were analyzed by simple weighting for each indicator, then analyzed to obtain performance for each year. The results showed that the operation irrigation at Dimoro Irrigation Area tend to succeed if seen from its performance that rises.
\end{abstract}

Keyword : operation irrigation, performance,rating scale methods.

\section{Introduction}

As a country agrarians, the majority of the population Indonesia drape live on agriculture. Indonesia prioritize the agricultural sector development. Sector development is aimed to increase the welfare of farmers through the agricultural production [1]. To increase agricultural production needs to pay attention to the role of irrigation. The contribution of infrastructure and facilities irrigation against food security during would be quite substantial, namely as many as 84 percent national rice production is sourced from the area of irrigation [2].

It is the same with one of vision Karanganyar district that is into splints the national bread. Karanganyar district located at $110^{\circ} 40^{\prime}-110^{\circ} 70^{\prime}$ East Longitude and $7^{\circ} 28^{\prime}-$ $7^{\circ} 70^{\prime}$ South Altitude. Agriculture became important in the underpinning of Karanganyar Regency because utilization has extensive wetland $22,130.32$ ha of the total area $77,378.64$ ha. One of the areas of irrigation in Karanganyar Regency is Dimoro. The location is shown in Figure 1. DI Dimoro irrigates five villages in Karangpandan Sub District with standard width of 493.64 ha. The government allocates budget for operational and irrigation maintenance costs annually. In practice, some operation constraints and damages occur in the network harming the water distribution in 
irrigation network, so that there should be appropriate operational control and routine maintenance. Maintenance activity conducted in Sungkur irrigation area of Ponorogo Regency is not affecting the condition of irrigation building, and it has decreasing trend $[3]$.

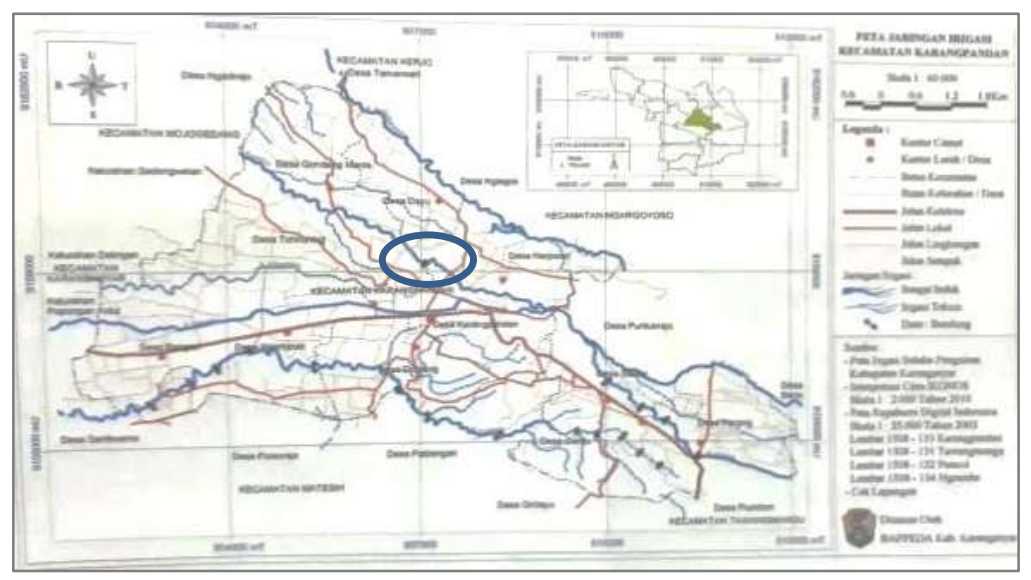

Figure 1. Research Location

The indicators of irrigation operation performance are the improved efficiency of water use, the increased planting intensity, the decreased water distribution conflict, the improved farm productivity, and the decreased level of plant drought [4]. Research should be conducted to find out the performance of irrigation operation in DI Dimoro from 2013 to 2016.

\section{Literature Review}

The study conducted on Sungkur irrigation area of Ponorogo Area mentioned that the condition value of irrigation network had a decreasing trend. Maintenance from 2007 to 2009, but it has not affected the component of irrigation building [3]. The style for every paragraph is BodytextIndented style

Irrigation management is one of the support sectors for agricultural development, especially to increase food production of rice. But with progress irrigation management performance has decreased caused by several reasons such as : the activity of care; repair or maintenance irrigation network a delayed ( divert); damage by human behavior and natural disaster. Any damage of irrigation network and the availability of maintenance fund, cause delayed or less good maintenance irrigation network [5].

The evaluation of irrigation system performance is a means of representing an irrigation system's condition and characteristic. In evaluating the performance of irrigation system, there are some points to consider concerning water providing adequacy and appropriateness, irrigation efficiency, drainage system condition and function, etc. The evaluation of irrigation system performance will be inseparable from Operation and Maintenance Irrigation Canal Activity. An irrigation canal's operation and maintenance play a role in an irrigation system's performance. The operation and 
maintenance of irrigation canal will provide the performance of irrigation system as well [6].

The performance of the irrigation system using remote sensing techniques at Water User's Associations (WUAs) in Lower Gediz Basin, West Turkey based on five indicators: overall consumed ratio (E), relative water supply (RWS), depleted fraction (DF ), Crop water deficit (CWD), and relative evapotranspiration (RET). The potential and actual evapotranspiration parameters are estimated in accordance with the Surface Energy Balance Algorithm (SEBAL) using the NOAA-16 satellite imaging method. The results of the seasonal average score of all performance indicators show that the irrigation water supply is less than the Water User Association needs. Nearness between irrigation area and the water source will be an advantage to obtain water and when is insufficient, groundwater in the root area of the plant may be used, as a impact of few precipitation and/or inefficient irrigation [7].

Evaluation of irrigation performance and water productivity by remote sensing satellite data and secondary data of agricultural production in Rechna Doab irrigation system at Punjab Pakistan is conducted to design appropriate water management strategies. So the irrigation systems can be managed to improve overall performance and increase a sustainable water productivity. Supply and demand of water data by remote sensing estimation, which are combined with secondary agricultural production data, provide a better estimation of irrigation performance, including water productivity at some alternative scales. Remote sensing based indicators to estimate fairness, adequacy, reliability and water productivity [8].

The performance indicators is referred to farmers satisfaction as an indicator of social performance, whereas physical and financial performance indicators show the performance of irrigation water management, as a determinant factor using the Logit Model. These indicators are implemented into 2 (two) stages on the Bursa-Karacabey (KIS) irrigation network, Western Turkey. In the first stage, water management performance is assessed using 2 (two) physical indicators, that is average irrigation ratio and relative water supply and 3 (three) financial performance indicators, that is financial adequacy of budget management, operation and maintenance, and the number of staff per unit area. In the second phase, irrigation management is tested and assessed by Logit Model, take a farmer's perception of satisfaction on irrigation service, that is cost policy of irrigation and maintenance of irrigation and drainage. One of the reasons why the performance of the irrigation system is not achieved, because performance improvement is emphasized on physical infrastructure and ignores the social dimension, so participatory irrigation management is included in the operation of irrigation systems [9].

The damage of irrigation network in North Gambia in the last two decades due to poor maintenance. The less optimal performance and damage occurring in irrigation building require rehabilitation. Thus, in the last decade, there is a trend to focus on rehabilitating the existing irrigation network rather than on building the new irrigation [10]. 
In Bedena Alemtena irrigation network in Hallaba, South Ethiopia, to maintain the scheme of irrigation network in the best condition, it was recommended to monitor all irrigation network activities, to improve training and extension, and to make evaluation seasonally, the result of which should be conveyed to the efficient monitoring system. Water users, association, and cooperatives conducting irrigation operation and maintenance should be empowered better [11].

The operation system in $\mathrm{Cu}$ Chi irrigation in Vietnam is not consider crop water requirements and channel regulation. A retrospective operational analysis reveals that there is an oversupply in large quantities and inequality distribution of water. By simulation analisys and field evaluation, two new operating strategies are chosen to applicated. Operating system modeling is conducted by Irrigation Main System Operation (IMSOP). The new system shows a fairer distribution. The ratio of average pre-intervention supply-demand decreased from around 1.68 to 2.51 to be 1.20 for continuous flow and 1.17 for rotational flow [12].

The operation of irrigation depend on planting pattern \& percentage distribution, actual irrigation area, irrigation network and water distribution, water intake from irrigation, and different effect of irrigation method the farmers use. The operation actualization module is around $5 \%, 10 \%, 15 \%$ of operational loss and also without loss [13].

Upgrading of efficiency can increase the equity of water distribution and minimize the gap between water availability and water use. As a result, it will determine the effectiveness of water use and improve the living conditions of the people. Farmers use fewer water or investment, and obtain higher productivity. More water are left in the sources and the ecology and environment of the river basin well maintened [14].

The significant result of harvest, farmer income, and water productivity with the organized irrigation are compared with the disorganized irrigation [15]. Technically, the organization and distribution of irrigation water can be planned and conducted accurately and optimally based on the existing technology [16].

\section{Methods}

The methods applied in this study is descriptive quantitative by secondary data. The secondary data is particular sources that have been available before this study.

Secondary data is collected by obtaining the data of irrigation operation from 2013 to 2016. From the record in operation form, it can be found the ratio of water distribution implementation (RPPA), planting width plan to its realization (RRRT), and factor $\mathrm{K}$ values. Thus three elements become the indicators of water use efficiency. The record of planting form shows the value of planting intensity, annual rice productivity, plant drought and water distribution conflict. 


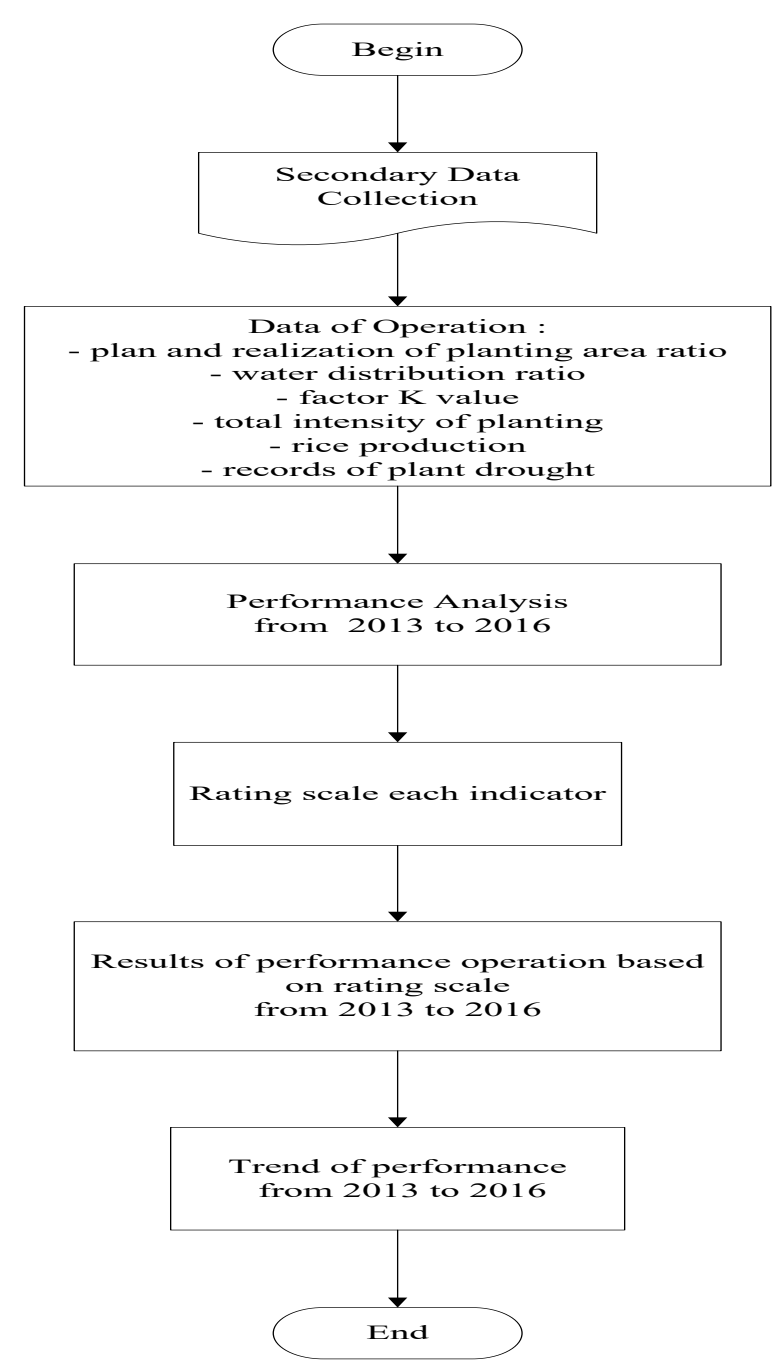

Figure 2. The flowchart of the research

\section{Research Results}

Water usage efficiency depends on three factors, there is factor $\mathrm{K}$, water distribution ratio (RPPA), and planned ratio and realization of planted area (it can be abbreviated as RRRT). The value of factor $\mathrm{K}$ represents the value obtained from the distribution of water available in the damn less the water loss in the main/secondary canal divided by the total water requirement of the whole plant. Ratio and realization of planted area are represent the value obtained from the value of planted area divided by the value of planned area. The value of RPPA is the comparison of the measured water volume at the time of checking with the volume plan.

Data processing is carried out based on Irrigation System Performance Monitoring and Evaluation Module in PSDA Service in 2010, obtaining the value of each indicator from 2013 to 2016. RPPA values for respective years are $0.73 ; 0.71 ; 0.78 ; 0.79$; RRRT values for respective years are $0.998 ; 0.998 ; 1.0 ; 1.0$; factor $\mathrm{K}$ value for respective years are $0.713 ; 0.823 ; 0.967 ; 1.0$; planting intensity values are $79.08 \% ; 79.86 \% ; 69.33 \%$; $100 \%$; rice productivity values for the respective years are the same, 100\%; plant 
drought values are $7.2 \% ; 7.2 \% ; 7.2 \% ; 0 \%$; meanwhile, regarding the conflict of water distribution for respective years shows that there is conflict adequately in 2013, rarely in 2015 and very rarely in 2016 . These results is shown in figure 3:

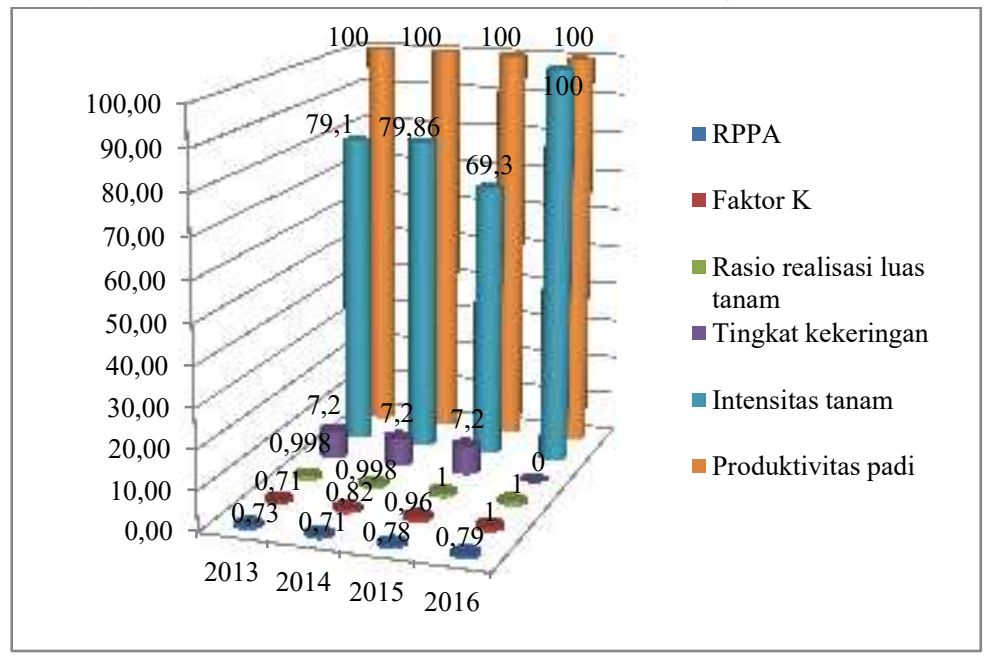

Figure 3. Results each indicator

Rating scale methods for each indicator is shown in table 1 below :

Table 1. Rating scale for each indicator

\begin{tabular}{|c|c|c|c|c|c|c|c|}
\hline Rating & $\begin{array}{l}\text { RPPA } \\
\text { value }\end{array}$ & $\begin{array}{c}\text { Factor K } \\
\text { value }\end{array}$ & $\begin{array}{c}\text { RRRT } \\
\text { value }\end{array}$ & $\begin{array}{c}\text { Planting } \\
\text { intensity (\%) }\end{array}$ & $\begin{array}{c}\text { Agricultural } \\
\text { produvtivity } \\
(\%)\end{array}$ & $\begin{array}{l}\text { Drought } \\
\text { level (\%) }\end{array}$ & $\begin{array}{c}\text { Water } \\
\text { distribution } \\
\text { conflict }\end{array}$ \\
\hline 1 & $<0,4$ & $<0,25$ & $0,0-0,2$ & $0-20,00$ & $0,0-20,0$ & $8,1-10$ & Very often \\
\hline 2 & $>1,4$ & $0,25-0,5$ & $0,21-0,40$ & $20,01-40,00$ & $20,1-40,0$ & $6,1-8,0$ & $\begin{array}{l}\text { Often } \\
\text { conflict }\end{array}$ \\
\hline 3 & $1,25-1,4$ & $0,5-0,75$ & $0,41-0,60$ & $40,01-60,00$ & $40,1-60,0$ & $4,1-6,0$ & $\begin{array}{l}\text { Quite } \\
\text { conflict }\end{array}$ \\
\hline 4 & $0,4-0,75$ & $0,75-1,0$ & $0,61-0,80$ & $60,01-80,00$ & $60,1-80,0$ & $2,1-4,0$ & $\begin{array}{l}\text { Rarely } \\
\text { conflict }\end{array}$ \\
\hline 5 & $0,75-1,25$ & $\geq 1,25$ & $0,81-1,00$ & $80,01-100,0$ & $80,1-100$ & $0,0-2,0$ & Very rarely \\
\hline
\end{tabular}

From those rating, are gained the values of each indicator in every year starting from 2013 to 2016. The value of RPPA based on rating scale is $4 ; 4 ; 5 ; 5$. The value of factor $\mathrm{K}$ based on rating scale is $4 ; 5 ; 5 ; 5$. The value of RRRT based on rating scale is $5 ; 5 ; 5$; 5 . The value of rice productivity based on rating scale is $5 ; 5 ; 5 ; 5$. The value of planting intensity based on rating scale is $4 ; 4 ; 4 ; 5$. The value of drought level based on rating scale is $2 ; 2 ; 2 ; 5$. The value of water distribution conflict based on rating scale is $3 ; 4$; $5 ; 5$. Can be seen in figure 4.

Value based rating scale methods every indicator have been found from the year 2013 until 2016. Next analysis performance was done with assumed that weight to every indicator performance is the same of the importance. Total weight is $100 \%$. The Results analysis presents in table 2 . 
Table 2. Results Analysis

\begin{tabular}{cccccc}
\hline Years & $(\%)$ & 2013 & 2014 & 2015 & 2016 \\
\hline Indicators & Weight & Value & Value & Value & Value \\
\hline RPPA value & 6,67 & 5,33 & 5,33 & 6,67 & 6,67 \\
Factor K value & 6,67 & 5,33 & 6,67 & 6,67 & 6,67 \\
RRRT value & 6,67 & 6,67 & 6,67 & 6,67 & 6,67 \\
Planting intensity & 20 & 16 & 16 & 16 & 20 \\
Agricultural productivity & 20 & 20 & 20 & 20 & 20 \\
Drought level & 20 & 8 & 8 & 8 & 20 \\
Water distribution conflict & 20 & 12 & 16 & 20 & 20 \\
\hline Performance & & 73,33 & 78,67 & 84 & 100 \\
\hline
\end{tabular}

The results of the analysis show that the performance in 2013 reached 73.33 which means good performance, in 2014 reached value 78.67 which means good performance, in 2015 reached value 84 which means very good performance, as well as in 2016 that achieve maximum value 100 which means very good performance. From these results with simple linear regression showed the tendency of performance on DI Dimoro from 2013 to 2016. The results can be seen in Figure 5.

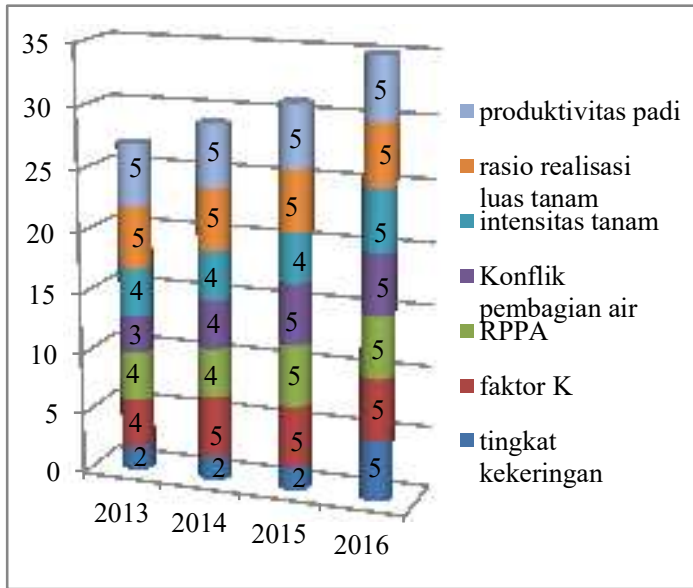

Figure 4. Rating scale each indicator

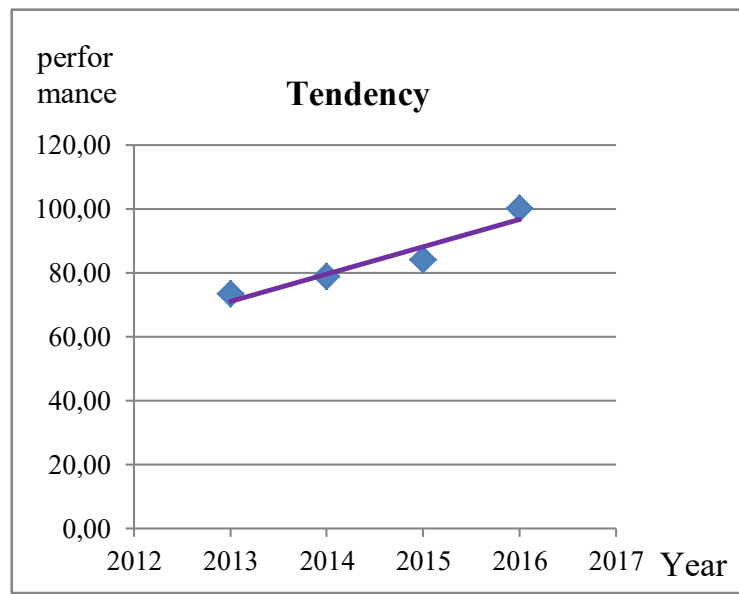

Figure 5. Tendency

In the year 2014 and above there is a change in the value of factor K. With the change in the value of factor $\mathrm{K}$, the weight gain also changed. In addition to the value of the $\mathrm{K}$ factor that changes the value of RPPA also changes. However, the change began to occur in 2015. For the RRRT value began to change in 2015 while the weight does not change because it is still within the limits of the same weight range. Changes also occur in water-sharing conflicts. From 2014 there has been a change until 2016. For the intensity of planting from 2013 to 2015 remains no change, but in the year 2016 there was change from 4 to 5. As for the drought level from 2013 to 2015 remains no change, but in 2016 there was a significant change from weight 2 to weight 5 . 
The overall indicators of irrigation operation in Dimoro shows the tendency of increasing in each year. The increasing can be seen from the performance graphs that show an increasing tendency. With the improvement of performance, it can be said that the implementation of irrigation operations in Dimoro experienced success.

\section{Research Results}

Based on the result of performance analysis of irrigation operation DI Dimoro Karanganyar can be concluded as follows:

1) Maximum performance results based on rating scale methods achieved in the year 2016 which reached the value of 100 .

2) Implementation of irrigation operations DI Dimoro from 2013 to 2016 tends to succeed when viewed from the graph of its performance increases each year.

\section{Acknowledgements}

This research was carried out with the financial support of Kementerian Pekerjaan Umum dan Perumahan Rakyat Republik Indonesia.

\section{References}

[1] Manurung, D.A., Sumono, S. Panggabean. 2016. Evaluasi Kinerja Operasi dan Pemeliharaan Sistem Irigasi Serbangan di Kecamatan Rawang Panca Arga Kabupaten Asahan. Jurnal Rekayasa Pangan dan Pertanian. 4. 4.

[2] Ansori Ahmad, Anton Ariyanto, M.Eng., dan Syahroni, ST. 2013. Kajian Efektifitas dan Efisiensi Jaringan Irigasi terhadap Kebutuhan Air pada Tanaman Padi (Studi Kasus Irigasi Kaito Samo Kecamatan Rambah Kabupaten Rokan Hulu). Jurnal Fakultas Teknik Universitas Pasir Pengaraian. 1, 1.

[3] Sucipto, Sobriyah, Agus H W. 2013. The Maintenance Evaluation of Sungkur Irrigation System at Ponorogo Regency : Procedia Engineering. 54 pp 661$\underline{667 .}$

[4] Anonim. 2010. Modul Pedoman Pemantauan dan Evaluasi Kinerja Sistem Irigasi (Dinas PSDA Kementerian Pekerjaan Umum Republik Indonesia).

[5] Sebayang, MS., Sumono, Achwil Putra Munir. 2014. Evaluasi Kinerja Operasi dan Pemeliharaan Sistem Irigasi Medan Krio di Kecamatan Sunggal Kabupaten Deli Serdang. Jurnal Rekayasa Pangan dan Pertanian. 2. 3. p: $116-$ 123.

[6] Setyawan C, Susanto, Sukirno. 2011. Evaluasi Kinerja Sistem Irigasi. J. Teknotan. 7. 2.

[7] Karatas, B.S., Akkuzu, E., Unal, H.B., Asik, S., and Avci, M. 2009. Using Satellite Remote Sensing to Assess Irrigation Performance in Water User Associations in the Lower Gediz Basin, Turkey. International Journal Elsevier Agricultural Water Management. 96. Issue 6. p: 982 - 990.

[8] Ahmad, M.D., Turral, H., and Nazeer, A. 2009. Diagnosing Irrigation Performance and Water Productivity through Satellite Remote Sensing and Secondary Data in a Large Irrigation System of Pakistan, International Journal 
Elsevier Agricultural Water Management. 96, Issue 4. p: 551 - 564.

[9] Kuscu, H., Boluktepe, F.E., and Demir, A.O. 2009. Performance Assessment for Irrigation Water Management : A case study in the Karacabey Irrigation Scheme in Turkey. African Journal of Agricultural Research. ISSN 1991637X. 4 (2). pp. $124-132$.

[10] Mutambara Solomon, Michael B K Darkoh, Julius R Atlhopeng. 2016. A Comparative Review of Water Management Sustainability Challenges in Smallholder Irrigation Kaito Schemes in Africa and Asia. J. Agricultural Water Management. 171 (Elsevier). pp 63-72.

[11] T Dessalew et al. 2016. Performance Evaluation of Bedena Alemtena Small Scale Irrigation Schemes in Hallaba Special Woreda Southern Ethiopia. Open Access Library J. 3. 2021.

[12] George, Biju A., Malano, Hector M., Vo Khac Tri, Turral, Hugh. 2004. Using modelling to improve operational performance in the $\mathrm{Cu}$ Chi irrigation system. Vietnam. Journal ICID.http://onlinelibrary.wiley.com/doi/10.1002/ird.109/abstract.

[13] Cengiz Koç. 2016. A Study on Planned and Applied Irrigation Modules in Irrigation Networks A Case Study at Buyuk Menderes Basin Turkey. $J$. Computational Water, Energy, and Enviromental Engineering. 5. pp 112-122.

[14] Phengphaengsy. F., et al. 2011. Improvement of Irrigation Efficiency in Paddy Fields in The Lower Mekong Basin Project (IIEPF). Journal of Mekong Research for The People of The Mekong. 18-2. 10.06.

[15] Pemeliharaan Sistem Irigasi Serbangan di Kecamatan Rawang Panca Arga Kabupaten Asahan. Jurnal Rekayasa Pangan dan Pertanian. 4. 4. 